\title{
Influence of $P$ Levels and PSB Seed Treatment on Productivity of Rainfed Maize (Zea mays L.) under Phosphorus Rich Acid Soils
}

\author{
T. Lavanya Bai*, B. C. Dhananjaya and M. Dinesh Kumar \\ Department of Soil Science and Agricultural Chemistry, College of Agriculture, \\ Shivamogga-577225, Karnataka, India \\ *Corresponding author
}

A B S T R A C T

\begin{tabular}{l} 
Ke y w o r d s \\
$\begin{array}{l}\text { Phosphorus, PSB, } \\
\text { Maize, Seed } \\
\text { treatment, Nutrient } \\
\text { content and uptake }\end{array}$ \\
\hline Article Info \\
$\begin{array}{l}\text { Accepted: } \\
\text { 07 March } 2020 \\
\text { Available Online: } \\
\text { 10 April } 2020\end{array}$ \\
\hline
\end{tabular}

A field experiment was carried out at College of Agriculture, Navile, Shivamogga during kharif 2016 to study the response of maize to different phosphorus $(\mathrm{P})$ levels with and without PSB seed treatment. The P levels were $0,30,45,60$ and $75 \mathrm{~kg} \mathrm{P}_{2} \mathrm{O}_{5}$ per ha ${ }^{-1}$ with and without PSB seed treatment were tried in a randomized complete block design with three replications and eleven treatments. The results of the experiment indicated that seed treatment with PSB and higher levels of P significantly increases the growth, yield and yield attributes and uptake of nutrients by maize. Among the treatments, treatment receiving $75 \mathrm{~kg} \mathrm{P}_{2} \mathrm{O}_{5}$ per ha ${ }^{-1}$ through DAP and PSB seed treatment recorded higher plant height $(207.15 \mathrm{~cm})$, total dry matter accumulation $\left(116.65 \mathrm{~g} \mathrm{plant}^{-1}\right)$, and yield parameter like cob length $(16.19 \mathrm{~cm})$, cob weight $\left(161.07 \mathrm{~g} \mathrm{plant}^{-1}\right)$, test weight $(37 \mathrm{~g})$, grain yield and stover yield (55.07 and $76.48 \mathrm{q} \mathrm{ha}^{-1,}$ respectively), and nutrient content and uptake of N, P, $\mathrm{K}$ by maize were also increased compared to other treatments and was on par with $75 \mathrm{~kg}$ $\mathrm{P}_{2} \mathrm{O}_{5}$ per ha ${ }^{-1}$ without PSB seed treatment and $60 \mathrm{~kg} \mathrm{P}_{2} \mathrm{O}_{5}$ per ha ${ }^{-1}$ with PSB seed treatment. The experiment evidently proved that $\mathrm{P}$ application @ higher levels with PSB seed treatment could enhance the growth, yield and yield attributes, nutrient content and uptake by maize.

\section{Introduction}

Maize (Zea mays L.), belongs to the family graminae, is third most important cereal crop after rice and wheat. India ranks $5^{\text {th }}$ in the world in Maize production. In India, maize is traditionally grown in monsoon (Kharif) season, in an area of 9.4 million hectare and contributes around 19.73 million tons accounting for an average yield of 1.9 MT ha $^{-1}$. Karnataka, Rajasthan, AP, UP, MP and Bihar are the leading states in India. In
Karnataka, crop is grown in an area of 1.30 million hectare, with an annual production of 4.40 million tons.

The productivity status either in India or in Karnataka is lower because of many reasons including mismanagement of plant nutrition. Though with many other constraints, limiting soil nutrient supply in different soils could be one of the major reasons for huge gaps between the actual and potential yields of the crop. 
Phosphorus (P) is an indispensable input for successful crop production in Agriculture. One unique characteristic of $\mathrm{P}$ is its low availability due to low diffusion and high fixation in soils. Being an essential element for plant growth and development, it is a component in key molecules such as nucleic acids, phospholipids and ATP and involved in regulation of enzymes.

Maize is often a better choice crop by resource poor farmers under rainfed conditions on marginal lands, which are poor in nutrient status and also suffer from moisture stress. In these lands, $\mathrm{P}$ deficiency is a wide spread constraint limiting crop productivity. Recommendations for $\mathrm{P}$ range from 60 to $75 \mathrm{~kg} \mathrm{ha}^{-1}$ for different growing regions in India and scheduled $\mathrm{P}$ be applied at the time of sowing as a basal-dressing in order to meet demand which is high during the early stages of crop growth.

Knowing the pattern of different forms of phosphorus helps in better understanding and calculating use efficiency of applied fertilizers. Kothandaraman and Krishnamurthy (1979) put forth the knowledge of various forms of phosphorus in the soil and the priorities under which these forms become available to plants which becomes a prerequisite in assessing the availability of phosphorus to plants since different forms have different solubilities.

Seed or soil inoculation with phosphate solubilizing microorganisms is known to improve solubilisation of fixed soil $\mathrm{P}$ and applied phosphates resulting in higher crop yields (Alagawadi and Gaur, 1988). However, it should also be possible to exploit the benefits of phosphate solubilizing organisms in soils where $\mathrm{P}$ is built up over the years from medium to high levels due to addition of phosphate fertilizers. This is because such native built-up can become a constant source of $\mathrm{P}$ to the crops if explored properly by using phosphorus solubilizing bacteria.

\section{Materials and Methods}

A field experiment was conducted at College of Agriculture, Navile, Shivamogga, Karnataka, India. The experimental site is situated at $14^{0} 0^{\prime}$ to $14^{0} 1$ ' North latitude and $75^{\circ} 40^{\prime}$ to $75^{\circ} 42^{\prime}$ East longitude with an altitude of 650 meters above the mean sea level during the period 2016-17. The experiment comprised 11 treatment combinations tried under field condition with maize hybrid 'Hema (NAH-1137)' as test crop.

The experiment was laid out in Randomized Complete Block Design (RCBD) with three replications. FYM at 10 tons $\mathrm{ha}^{-1}$ was applied two weeks before sowing. Before sowing, the seeds were treated with the Phosphorus solubilizing bacteria (PSB) (Bacillus megatherium) (375 $\mathrm{g} \mathrm{ha}^{-1}$ ), shade dried. Seed treatment was done as per the treatment details.

The different levels of $\mathrm{P}_{2} \mathrm{O}_{5}$ at the rate of 30 $\mathrm{kg} \mathrm{ha}^{-1}$ to $\mathrm{T}_{6}$ and $\mathrm{T}_{7}, 45 \mathrm{~kg} \mathrm{ha}^{-1}$ to $\mathrm{T}_{8}$ and $\mathrm{T}_{9}$, $60 \mathrm{~kg} \mathrm{ha}^{-1}$ to $\mathrm{T}_{10}$ and $\mathrm{T}_{11}$ with and without PSB seed treatment were tried. The recommended doses of fertilizers were applied @ 150: 75: $40 \mathrm{~N}, \mathrm{P}_{2} \mathrm{O}_{5}$, and $\mathrm{K}_{2} \mathrm{O} \mathrm{kg}$ $\mathrm{ha}^{-1}$. At the time of sowing 50 percent $\mathrm{N}$ and $\mathrm{K}$ and entire $\mathrm{P}$ were applied. Remaining 50 percent of $\mathrm{N}$ and $\mathrm{K}$ were applied at 30 days after sowing (DAS) as top dressing.

The growth, yield and yield parameters of maize were recorded. The grain and stover of maize were analyzed for nutrient content and uptake by following standard methods of analysis.

The treatment details are as follows $\mathrm{T}_{1}$ : control (No fertilizer), $\mathrm{T}_{2}: \mathrm{RDF}, \mathrm{T}_{3}: \mathrm{T}_{2}+\mathrm{PSB}$, 
$\mathrm{T}_{4}$ : RD N \& K only, $\mathrm{T}_{5}: \mathrm{T}_{4}+\mathrm{PSB}, \mathrm{T}_{6}: \mathrm{RD} \mathrm{N}$ $\& \mathrm{~K}+30 \mathrm{~kg} \mathrm{P}_{2} \mathrm{O}_{5} \mathrm{ha}^{-1}$ as DAP, $\mathrm{T}_{7}: \mathrm{T}_{6}+\mathrm{PSB}$, $\mathrm{T}_{8}$ : RD N \& $\mathrm{K}+45 \mathrm{~kg} \mathrm{P}_{2} \mathrm{O}_{5} \mathrm{ha}^{-1}$ as DAP, $\mathrm{T}_{9}$ : $\mathrm{T}_{8}+\mathrm{PSB}, \mathrm{T}_{10}: \mathrm{RD} \mathrm{N} \& \mathrm{~K}+60 \mathrm{~kg} \mathrm{P}_{2} \mathrm{O}_{5} \mathrm{ha}^{-1}$ as DAP, $\mathrm{T}_{11}: \mathrm{T}_{10}+\mathrm{PSB}$.

Initial characterization of soil for the experimental site indicated that soil was acidic in reaction $(\mathrm{pH}-5.58)$ with low organic carbon content $\left(4.8 \mathrm{~g} \mathrm{~kg}^{-1}\right)$. Further, the soil was medium in nitrogen $(439.04 \mathrm{~kg}$ $\left.\mathrm{ha}^{-1}\right)$, high in phosphorus status $(94.60 \mathrm{~kg}$ $\mathrm{ha}^{-1}$ ) and high with respect to available potassium status $\left(376.32 \mathrm{~kg} \mathrm{ha}^{-1}\right)$.

The exchangeable $\mathrm{Ca}$ and $\mathrm{Mg}$ was 4.40 and $2.40\left[\mathrm{cmol}\left(\mathrm{p}^{+}\right) \mathrm{kg}^{-1}\right]$, respectively. Whereas, available $\mathrm{S}$ was deficient $(8.38 \mathrm{ppm})$. The micronutrient status of soil was high with respect to $\mathrm{Fe}$ (26.66 ppm), Mn (28.42 ppm), $\mathrm{Zn}(2.13 \mathrm{ppm})$ and $\mathrm{Cu}(1.17 \mathrm{ppm})$. It belongs to the taxonomic class of Typic haplustalf with sandy loam texture.

\section{Results and Discussion}

The significant differences were noted in growth parameters of crop due to different levels phosphorus and PSB seed treatment as presented in Table 1. The treatment receiving 100 per cent recommended dose of fertilizer with PSB seed treatment recorded higher growth parameters like plant height and total dry matter accumulation at harvest followed by recommended dose of fertilizer when compared to control (No fertilizer) followed by no-P applied treatment. It might be due to the application of varied levels of P and PSB treatment.

Significant differences were noticed among the treatments for yield and yield attributes like cob length, cob weight, test weight, grain and stover yield as presented in Table 2 . Application of 100 per cent RDF + PSB $\left(T_{3}\right)$ significantly increased the yield parameters of maize over RD-N\&K + No-P with and without PSB as well as RD-N\&K + 45\% RD$P$ with and without PSB. Cob weight and test weight were also higher due to high $\mathrm{P}$ availability in soil, which in turn influenced the physiological processes that are directly related to photosynthesis and carbohydrate translocation to cob growth as reported by Abbas Akbari et al., (2010).

The significant differences were noticed in nutrient content and uptake by maize due to different levels of $\mathrm{P}$ with and without PSB seed treatment. The plots treated with 100 per cent RDF + PSB $\left(T_{3}\right)$ significantly increased the nutrient content and uptake of Primary nutrient and Micro nutrient $(\mathrm{N}, \mathrm{P}$ and $\mathrm{K}$ respectively) and was on par with $75 \mathrm{~kg} \mathrm{P}_{2} \mathrm{O}_{5}$ per ha ${ }^{-1}$ without PSB seed treatment and $60 \mathrm{~kg}$ $\mathrm{P}_{2} \mathrm{O}_{5}$ per ha ${ }^{-1}$ with PSB seed treatment Figure $1 \& 2$. The nutrient content and uptake by maize were analyzed after harvest of the crop.

There was an increased nutrient content and also uptake in all the treatments except control. Phosphorus fertilization which helped in promoting root growth and efficient functioning of PSB which in turn increased microbial activity improving $\mathrm{N}$ availability and increased the content and uptake of $\mathrm{N}$ by maize.

Kishore Babu and Seshaiah (2006) observed that concentration and uptake of nutrients in grain and straw increased linearly with an increase in $\mathrm{P}$ levels in combinations with organic manures and PSF. However, the content and uptake of potassium increased significantly with application of RDF+PSB compared to RDF alone and RD-N\&K + 50 $\%$ RD-P + PSB treatments. The higher uptake may be due to the higher biomass production. Similar observations were found by Rao and Bharadwaj (1981) and Hariprasad et al., (1990). 
Table.1 Effect of P levels and PSB seed treatment on plant height and total dry matter accumulation at different growth stages of maize

\begin{tabular}{|c|c|c|c|c|}
\hline \multirow[t]{2}{*}{ Treatments } & \multicolumn{3}{|c|}{ Plant height (cm) } & \multirow{2}{*}{$\begin{array}{l}\text { Total dry matter } \\
\text { accumulation at } \\
\text { harvest }\left(\mathrm{g} \text { plant }^{-1}\right)\end{array}$} \\
\hline & 45 DAS & 90 DAS & Harvest & \\
\hline $\mathbf{T}_{1}:$ Control (No fertilizer) & 71.92 & 161.43 & 174.95 & 43.71 \\
\hline$T_{2}:$ Recommended NPK $\left(150: 75: 40 \mathrm{~kg} \mathrm{ha}^{-1}\right) \mathrm{P}_{2} \mathrm{O}_{5}$ as DAP & 129.91 & 193.51 & 198.37 & 106.44 \\
\hline$T_{3}:$ Recommended NPK + PSB & 131.29 & 202.33 & 207.15 & 116.65 \\
\hline $\mathbf{T}_{4}:$ Recommended NK only & 94.73 & 179.96 & 186.81 & 58.36 \\
\hline $\mathbf{T}_{5}: \mathbf{T}_{4}+\mathrm{PSB}$ & 102.79 & 183.43 & 189.40 & 66.30 \\
\hline $\mathrm{T}_{6}: \mathrm{T}_{4}+30 \mathrm{~kg} \mathrm{P}_{2} \mathrm{O}_{5} \mathrm{ha}^{-1}$ as DAP (40 \% of recommended $\left.\mathrm{P}\right)$ & 108.53 & 184.40 & 189.59 & 71.56 \\
\hline $\mathrm{T}_{7}: \mathrm{T}_{4}+30 \mathrm{~kg} \mathrm{P}_{2} \mathrm{O}_{5} \mathrm{ha}^{-1}$ as DAP $+\mathrm{PSB}(40 \%$ of recommended $\mathrm{P})$ & 113.35 & 185.13 & 189.91 & 79.85 \\
\hline $\mathrm{T}_{8}: \mathrm{T}_{4}+45 \mathrm{~kg} \mathrm{P}_{2} \mathrm{O}_{5} \mathrm{ha}^{-1}$ as DAP $(60 \%$ of recommended $\mathrm{P})$ & 117.85 & 187.28 & 191.99 & 81.26 \\
\hline $\mathrm{T}_{9}: \mathrm{T}_{4}+45 \mathrm{~kg} \mathrm{P}_{2} \mathrm{O}_{5} \mathrm{ha}^{-1}$ as DAP + PSB $(60 \%$ of recommended P $)$ & 123.69 & 190.37 & 192.15 & 84.32 \\
\hline$T_{10}: T_{4}+60 \mathrm{~kg} \mathrm{P}_{2} \mathrm{O}_{5} \mathrm{ha}^{-1}$ as DAP $(80 \%$ of recommended $\mathrm{P})$ & 126.18 & 191.04 & 193.76 & 91.80 \\
\hline$T_{11}: T_{4}+60 \mathrm{~kg} \mathrm{P}_{2} \mathrm{O}_{5} \mathrm{ha}^{-1}$ as DAP + PSB $(80 \%$ of recommended P) & 128.52 & 191.14 & 195.58 & 96.54 \\
\hline S. Em. \pm & 9.16 & 6.46 & 9.07 & 3.97 \\
\hline C.D. $(p=0.05)$ & 27.45 & 19.38 & 27.19 & 11.71 \\
\hline
\end{tabular}


Table.2 Effect of P levels and PSB seed treatment on cob length, cob weight, test weight, grain and stover yield of maize

\begin{tabular}{|c|c|c|c|c|c|}
\hline Treatments & $\begin{array}{c}\text { Cob length } \\
(\mathrm{cm})\end{array}$ & $\begin{array}{c}\text { Cob weight } \\
\left(\text { g plant }^{-1}\right)\end{array}$ & $\begin{array}{c}\text { Test weight } \\
\text { (g) }\end{array}$ & \multicolumn{2}{|c|}{$\left(\mathbf{q} \mathbf{h a}^{-1}\right)$} \\
\hline$T_{1}:$ Control (No fertilizer) & 12.23 & 84.57 & 24.94 & 21.30 & 33.09 \\
\hline$T_{2}$ : Recommended NPK (150:75:40 $\left.\mathrm{kg} \mathrm{ha}^{-1}\right) \mathrm{P}_{2} \mathrm{O}_{5}$ as DAP & 15.87 & 154.43 & 35.34 & 50.61 & 67.78 \\
\hline$T_{3}:$ Recommended NPK + PSB & 16.19 & 161.07 & 37.01 & 55.07 & 76.48 \\
\hline $\mathrm{T}_{4}:$ Recommended NK only & 14.22 & 107.60 & 26.79 & 28.26 & 41.11 \\
\hline$T_{5}: T_{4}+$ PSB & 14.89 & 121.75 & 27.48 & 31.41 & 50.12 \\
\hline $\mathrm{T}_{6}: \mathrm{T}_{4}+30 \mathrm{~kg} \mathrm{P}_{2} \mathrm{O}_{5} \mathrm{ha}^{-1}$ as DAP (40 \% of recommended $\left.\mathrm{P}\right)$ & 15.31 & 122.03 & 27.96 & 36.15 & 53.33 \\
\hline $\mathrm{T}_{7}: \mathrm{T}_{4}+30 \mathrm{~kg} \mathrm{P}_{2} \mathrm{O}_{5} \mathrm{ha}^{-1}$ as DAP + PSB $(40 \%$ of recommended $\mathrm{P})$ & 15.42 & 129.07 & 28.78 & 37.38 & 53.33 \\
\hline $\mathrm{T}_{8}: \mathrm{T}_{4}+45 \mathrm{~kg} \mathrm{P}_{2} \mathrm{O}_{5} \mathrm{ha}^{-1}$ as DAP $(60 \%$ of recommended $\mathrm{P})$ & 15.55 & 132.77 & 29.92 & 39.36 & 55.31 \\
\hline $\mathrm{T}_{9}: \mathrm{T}_{4}+45 \mathrm{~kg} \mathrm{P}_{2} \mathrm{O}_{5} \mathrm{ha}^{-1}$ as DAP + PSB $(60 \%$ of recommended $\mathrm{P})$ & 15.68 & 142.07 & 30.42 & 44.62 & 57.65 \\
\hline$T_{10}: T_{4}+60 \mathrm{~kg} \mathrm{P}_{2} \mathrm{O}_{5} \mathrm{ha}^{-1}$ as DAP $(80 \%$ of recommended $\mathrm{P})$ & 15.51 & 148.00 & 31.39 & 46.29 & 57.78 \\
\hline$T_{11}: T_{4}+60 \mathrm{~kg} \mathrm{P}_{2} \mathrm{O}_{5} \mathrm{ha}^{-1}$ as DAP + PSB $(80 \%$ of recommended P $)$ & 15.77 & 150.57 & 33.10 & 48.39 & 64.69 \\
\hline S. Em. \pm & 0.40 & 4.68 & 0.72 & 3.43 & 5.10 \\
\hline C.D. $(p=0.05)$ & 1.18 & 13.80 & 2.13 & 10.13 & 15.05 \\
\hline
\end{tabular}

Note: FYM is common to all the treatment

*DAS- Days after sowing 
Fig.1 Effect of P levels with or without PSB seed treatment on nutrient content by maize

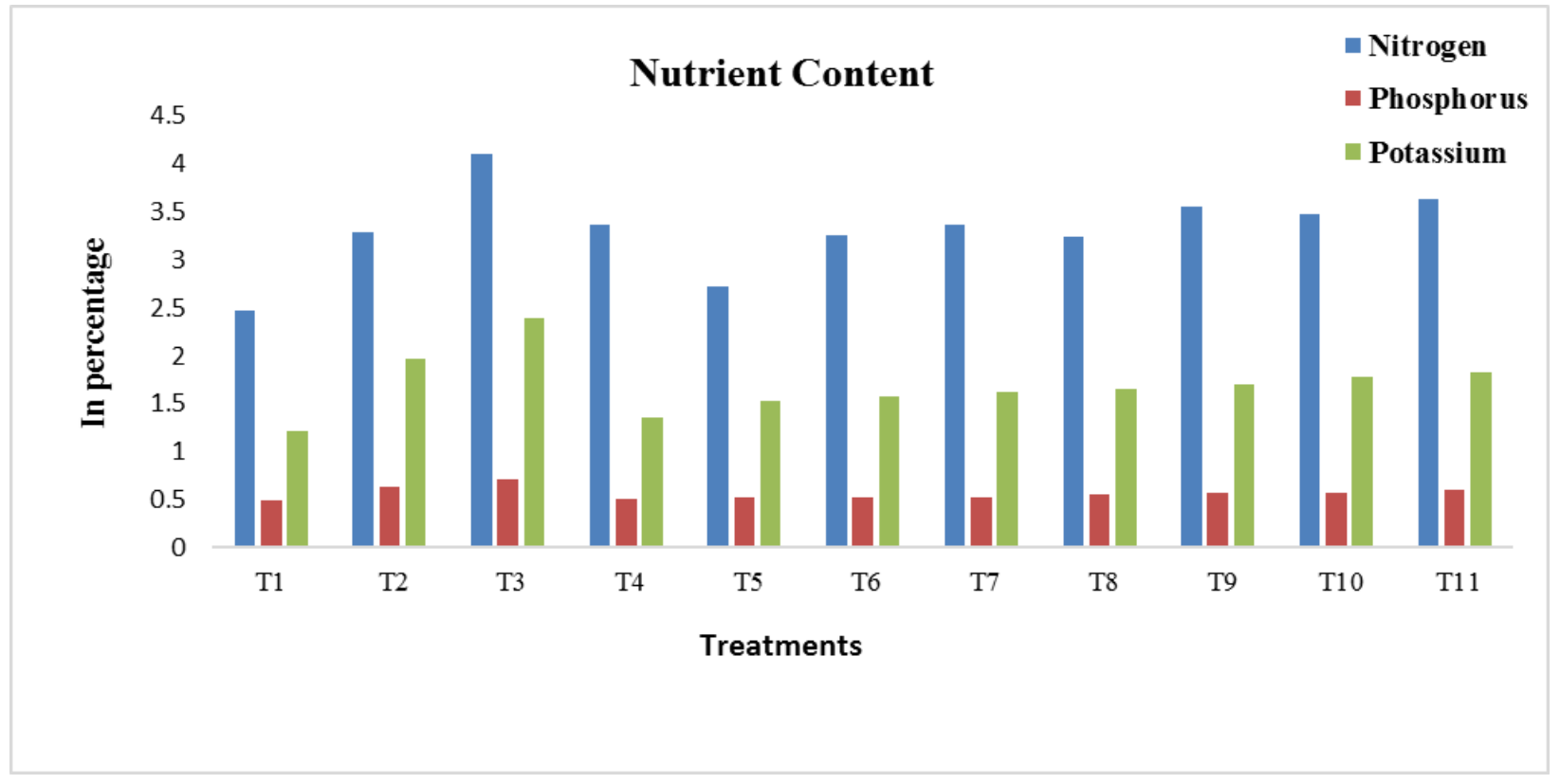

Fig.2 Effect of P levels with or without PSB seed treatment on nutrient uptake by maize

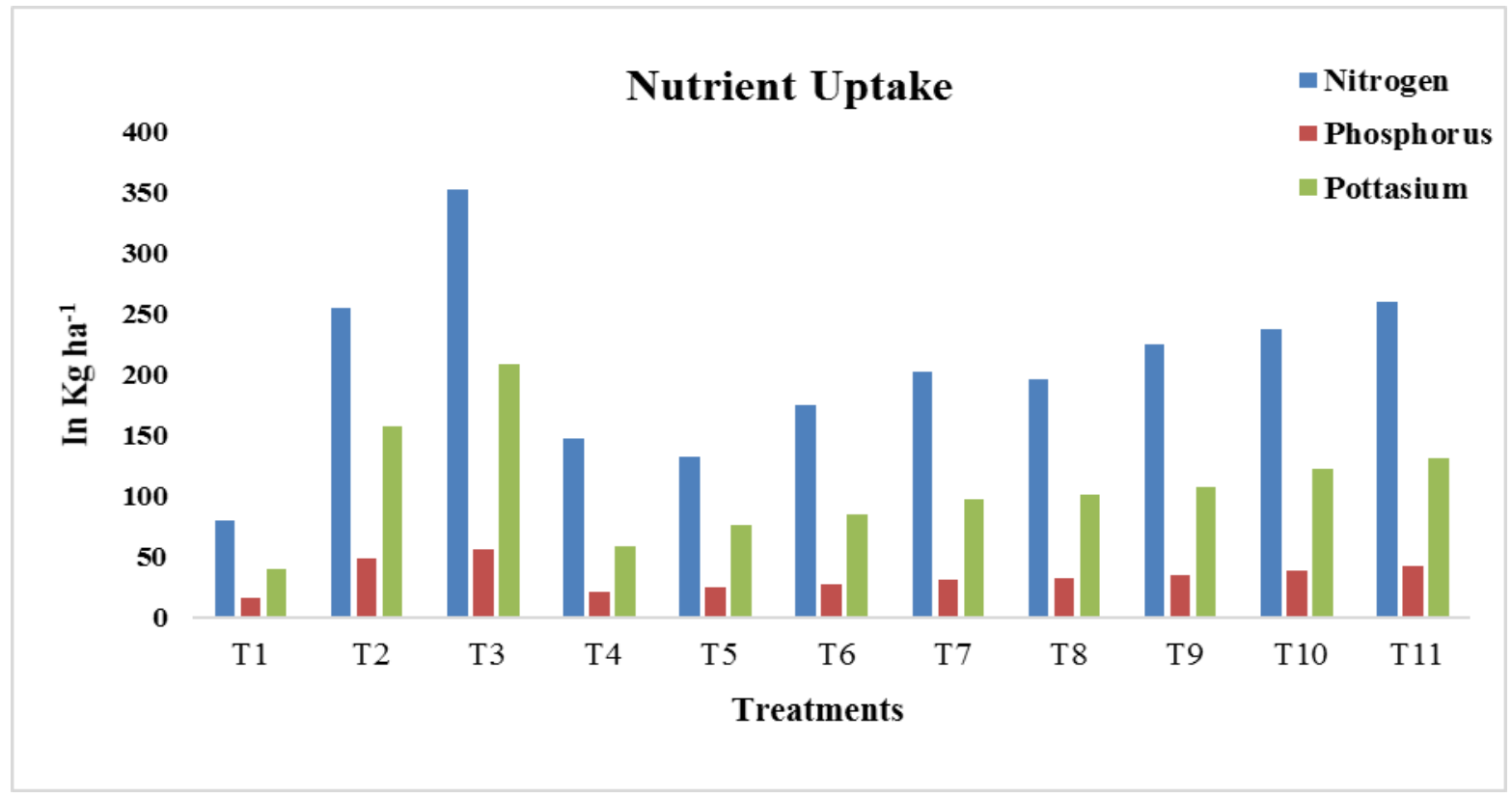

In Conclusion from the experimental results it can be concluded that, application of higher $\mathrm{P}$ levels with or without PSB seed treatment significantly enhanced the growth, yield and yield attributes of maize. The content and uptake of $\mathrm{N}, \mathrm{P}$, and $\mathrm{K}$ by maize was also higher in treatments with $100 \% \mathrm{P}$ application
+ PSB followed by $100 \% \mathrm{P}$ application compared to rest of the treatments.

\section{References}

Abbas Akbari, G. H., Eftekhari, G. H. and Allahdadi, I., 2010, Evaluation of rock 
and super phosphates effects on yield and yield components of Rice (Oryza sativa L.) with and without phosphate solubilizing bacteria. Am. J. Agron., 3(3): 51-58.

Alagawadi, A. R. and Gaur, A. C., 1988, Associative effect of Rhizobium and phosphate solubilizing bacteria on the yield and nutrient uptake of chickpea. Pl. Soil, 105: 241-246.

Bukvic, G., Antunovic, M., Popovic, S. and Rastija, M., 2003, Effect of P and Zn fertilization on biomass yield and its uptake by maize lines (Zea mays L.). Pl. Soil Environ., 49(11): 505-510.

Hariprasad Rao, K., Krishna Kumari, G. and Pillai, R. N., 1990, Effect of phosphate application on nutrient composition and yield of Blackgram on Vertisols.
J. Indian Soc. Soil Sci., 38: 546-547.

Kishore Babu, G. and Seshaiah, B. V., 2006, Effect of phosphates on yield and nutrient uptake in paddy Department of Soil Science and Agricultural Chemistry, Agricultural College, Bapatla-522 101, India. Agropedology, 16(1): 50-53.

Kothandaraman, G. V. and Krishnamoorthy, K. K., 1979, Forms of inorganic phosphorus in Tamil Nadu soils. Indian Soc. Soil Sci. Bull., 12: 243248.

Rao, J. V. and Bhardwaj, R. B. L., 1981, Response of maize to fertilizer and their residual and cumulative effects on the following wheat crop. Indian J. Agron., 26(4): 393-397.

\section{How to cite this article:}

Lavanya Bai, T., B. C. Dhananjaya and Dinesh Kumar, M. 2020. Influence of P Levels and PSB Seed Treatment on Productivity of Rainfed Maize (Zea mays L.) under Phosphorus Rich Acid Soils. Int.J.Curr.Microbiol.App.Sci. 9(04): 545-551. doi: https://doi.org/10.20546/ijcmas.2020.904.066 